\section{Acknowledgements}

I gratefully acknowledge assistance provided by Kenneth E. Johnston, Atmospheric Environment Service, Saskatoon, and by staff of Canadian Wildlife Service, Saskatoon.

${ }^{1}$ BERKEY, G., B. GOLLOP, J.A. GRZY BOWSKI, T.A. IMHOF, H.E. KINGERY, G.W. LASLEY AND C. SEXTON, B.G. PETERJOHN, D.J. POWELL, T.H. ROGERS, D. STEJSKAL, J. WITZEMAN. 1988. Am. Birds 42, No.3.

${ }^{2}$ BERKEY, G. 1988. Northern Great Plains region. Am. Birds 42:453.

${ }^{3}$ COPLAND, H. 1988. Manitoba Museum of Man and Nature, Winnipeg. Pers. comm.

${ }^{4}$ DE SCHAUENSEE, R.M. 1970. A guide to the birds of South America. Livingston Publ., Wynnewood, PA. 470 pp.

${ }^{5}$ DICKSON, R. 1988. Calgary, AB. Pers. comm.

${ }^{6}$ FARRAND, J. 1983. The Audubon Society master guide to birding. Vol. 2. Alfred A. Knopf, Inc. 398 pp.

${ }^{7}$ GODFREY, W.E. 1986. The birds of Canada. Nat. Mus. of Canada. 595 pp.

${ }^{8}$ GOSSELIN, M. and N. DAVID. 1982. Quebec region. Am. Birds 36:958.
${ }^{9}$ IMHOF, T.A. 1988. Central southern region. Am. Birds 42:448.

${ }^{10}$ JOHNSTON, K.E. 1988. Saskatoon Weather Office. Pers. comm.

${ }^{11}$ MCGILLIVARY, B. 1988. Prov. Mus. and Archives, Edmonton, AB. Pers. comm.

${ }^{12}$ MONROE, B.L. and A. BARRON. 1980. The Fork-tailed Flycatcher in North America. Am. Birds 34:842.

${ }^{13}$ OUELLET, H. 1988. Nat. Mus. of Canada. Pers. comm.

${ }^{14}$ PETERIOHN, B.G. 1984. Middlewestern prairie region. Am. Birds 38:206.

${ }^{15}$ RIDGELY, R.S. 1976. A guide to the birds of Panama. Princeton University Press, Princeton, NJ. $394 \mathrm{pp}$.

${ }^{16}$ SALT, W.R. and J.R. SALT. 1976. The birds of Alberta. Hurtig Publ., Edmonton. 498 pp.

${ }^{17}$ SCOTT, S.L. 1983. Field guide to the birds of North America. National Geographic Society, Washington, DC. $464 \mathrm{pp}$.

${ }^{18}$ SHADICK, S.J. 1988. Saskatoon, SK. Pers. comm.

${ }^{19}$ TABER, B. 1989. Williamsburg, VA. Pers. comm.

${ }^{20}$ TESSEN, D.D. 1988. Western Great Lakes region. Am. Birds 42:1292.

\title{
TURKEYS AT CLAIR, SASKATCHEWAN
}

IAMES H. PURDY, Box 123, Frog Lake, Alberta. TOA 1 M0

At approximately 11:00 a.m. 29 December 1988, an unusual sighting was made from Highway 5 just east of Clair, Saskatchewan. Very close to the north side of the road, in a small grove of poplars, three large, dark objects appeared in the trees. As my vehicle approached the trees, my first impression was that these objects were raccoons; my next impression was porcupines; my third impression was black plastic garbage bags! As the car passed the small bluff, the objects moved, revealing that they were birds - large, dark birds. 
I turned the car and drove back, parking on the shoulder of the highway, 20-25 $m$ from the poplars. The birds were roosting 3-4 $\mathrm{m}$ from the ground. Visibility was about $1 \mathrm{~km}$ with very light powdery snow. My wife and I and our two children had the opportunity to observe the birds under favourable conditions using 7×35 binoculars and a copy of Birds of North America. ${ }^{8}$

The only large bird which could possibly meet the descriptions of these three was a Wild Turkey. This was reinforced by comparing field marks with the field guide.

The nearest of the three birds had a definite lightening of colour around the head which made me think of a Turkey Vulture. However, there was no distinct line between black body and red, naked head as in that case. This bird had an indistinct margin between body and a whitish upper neck and head, with some red overtones, particularly along the front. I am familiar with Turkey Vultures and am convinced that this was not what was perching in the trees. Godfrey differentiates Wild Turkeys from domesticated fowl by the former having tails tipped with brown and the latter tipped with whitish or pale buff. ${ }^{2}$ This bird had some rusty-coloured upper tail coverts, though I did not notice this reddish coloration continuing down the complete tail, and the tip appeared black. The birds were observed for 5 to 10 minutes until a passing truck caused them to drop into the grasses and bushes below their roost, where they soon moved out of sight.

Although I am not familiar with these birds other than observing them at Polar Park, Ardrossan, Alberta, Wild Turkeys have been sighted previously in Saskatchewan. They were first reported in the 1980 Christmas Bird Count at Biggar and regularly thereafter with the exception of 1984 and 1985. Most of these sightings have been in the Cypress Hills. ${ }^{134567}$

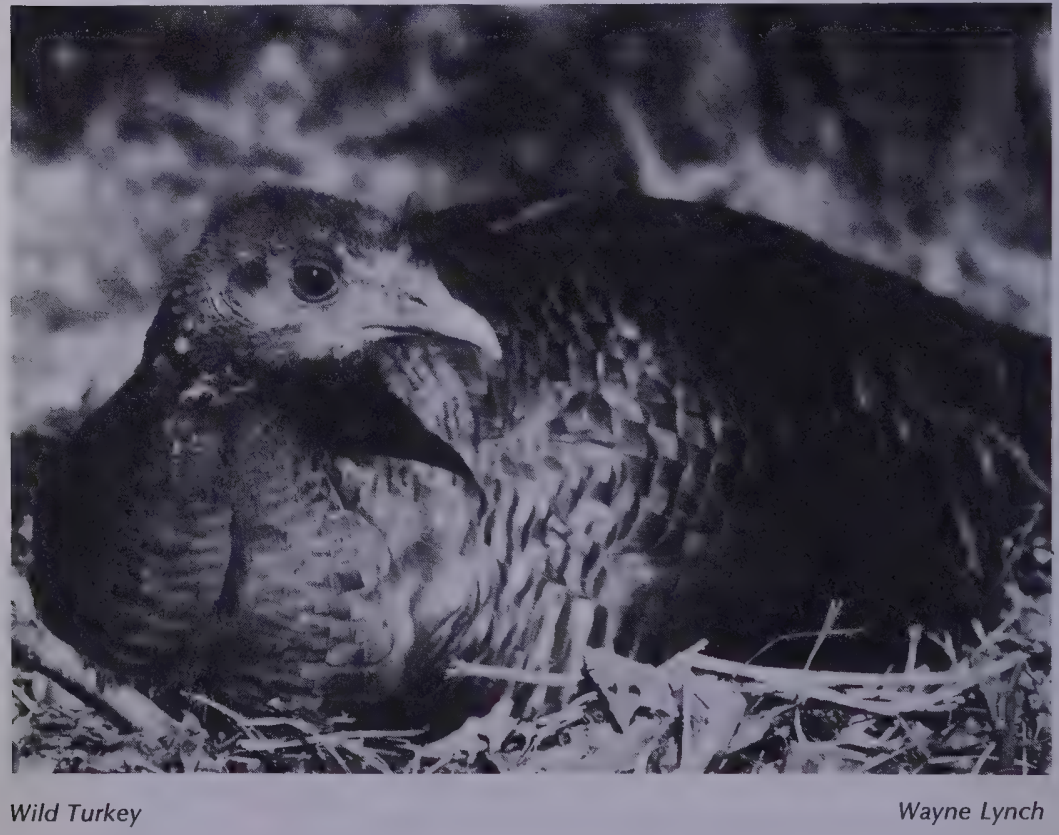


Clair, Saskatchewan, is a long way from the turkey's natural range. I am curious to know whether other sightings of these birds have been made in this area. Speculation leads me to wonder if these Wild Turkeys were released or had escaped from a neighbouring farm.

1 BELCHER, MARGARET. 1982. 40th annual Saskatchewan Christmas Bird Count-1981. Blue Jay 40:17-29.

${ }^{2}$ GODFREY, W.E. 1966. The birds of Canada. Nat. Mus. of Canada Bull. No. 203, Biol. Ser. No. 73. $428 \mathrm{pp}$.

${ }^{3}$ HOUSTON, M.I. 1981. 39th annual Saskatchewan Christmas Bird Count-1980. Blue Jay 39:13-24.
4 1983. 41st annual Saskatchewan Christmas Bird Count-1982. B/ue Jay $41: 12-25$. 1984. 42nd annual Sasskatchewan Christmas Bird Count-1983. Blue Jay 42:26-39.

6 1987. 45th annual Saskatchewan Christmas Bird Count-1986. Blue Jay 45:4-19.

7 1988. 46th annual Saskatchewan Christmas Bird Count-1987. Blue Jay 46:9-28.

BOBBINS, C.S., B. Bruun and H. S. Zim. 1966. A guide to field identification. Birds of North America. Golden Press. New York, N.Y. 340 pp.

\section{MELANISM AND HAIRLESSNESS IN THE RICHARDSON'S GROUND SQUIRREL}

HUGH C. SMITH, Provincial Museum of Alberta, 12845-102 Avenue, Edmonton, Alberta. T5N $0 \mathrm{M} 6$

Aberrant pelages in the rodent family Scuiridae are not unusual. In some species, such as Woodchuck, melanism and albinism occur on a regular basis. In other species such as the Gray Squirrel, the melanistic morph occurs in some populations to the exclusion of the normal morph. Other species exhibit little or no pelage aberrations. The Richardson's Ground Squirrel is one such species. I have been able to find one reference to albinism ${ }^{1}$ and none to melanism in this species. Recently, the Provincial Museum of Alberta received two specimens of Richardson's Ground Squirrel that are worth reporting because of their aberrant pelage.
The first specimen, a melanistic form (PMA No. 88.16.1), was obtained in the Didsbury area of central Alberta in June 1988. The individual is well furred with hair of normal length but entirely black in colour. The specimen was collected in a roadside ditch beside a field that was used to pasture livestock. A number of other black ground squirrels ( 25 to 30 ) along with a large number of normal-coloured individuals was observed in this pasture. An interview with a person who lived nearby revealed that the landowner allowed the shooting of "gophers" on this land, but only if they were of normal colour. The black individuals were not to be shot. The following standard 